Scientia Marina 71(1)

March 2007, 115-121, Barcelona (Spain)

ISSN: 0214-8358

\title{
The exploited population of the brackish river prawn (Macrobrachium macrobrachion Herklots 1851) in the Cross River estuary, Nigeria
}

\author{
FRANCIS M. NWOSU, SIEGHARD HOLZLÖHNER and UDEME I. ENIN \\ Institute of Oceanography, University of Calabar, P. M. B. 1115, Calabar, 540004 Cross River State, Nigeria. \\ E-mail: uienin@yahoo.com
}

\begin{abstract}
SUMMARY: The dynamics of the exploited population of Macrobrachium macrobrachion in the Cross River estuary, Nigeria, were studied based on monthly length-frequency data collected from January 1997 to June 1998 (18 months), from the landings of the artisanal Macrobrachium fishery. Sexual dimorphism was indicated in the growth and mortality parameters. For the males, the von Bertalanffy growth parameters were estimated as $\mathrm{L}_{\infty}=141.35 \mathrm{~mm}, \mathrm{~K}=1.21$ year ${ }^{-1}, \mathrm{C}=1.0$ and $\mathrm{WP}=0.15$. For the females, they were $\mathrm{L}_{\infty}=117.55 \mathrm{~mm}, \mathrm{~K}=1.60$ year ${ }^{-1}, \mathrm{C}=0.81$ and $\mathrm{WP}=0.51$. The instantaneous rate of total mortality (Z) was estimated as 9.53 year $^{-1}$ (males) and 9.14 year $^{-1}$ (females). The instantaneous rate of natural mortality (M) was estimated as 2.44 year $^{-1}$ (males) and 3.09 year $^{-1}$ (females), while the instantaneous rate of fishing mortality (F) was estimated as 7.09 year $^{-1}$ (males) and 6.05 year $^{-1}$ (females). The exploitation rate (E) obtained was 0.74 for the males and 0.66 for the females, suggesting that the prawn population was over-fished for both sexes. It is necessary to analyse the catch and effort data for the last 10 years and to apply other methods of stock assessment in order to estimate the long term trends in the fishery.
\end{abstract}

Key words: Macrobrachium macrobrachion, prawns, population dynamics, Cross River Estuary, Nigeria.

Summary: DinÁmica de la población eXPlotada de Brackish River Prawn (MacrobranchiUm macrobranchiUm Herklots 1851) En el eStuario del Cross River, Nigeria. - Se estudió la dinámica de la población explotada de Macrobranchium macrobranchium en el estuario del Cross River en Nigeria en base a las frecuencias de tallas mensuales desde enero de 1997 hasta junio de 1998 (18 meses), procedentes de los desembarcos de la pesquería artesanal. El crecimiento y la mortalidad fueron calculados separadamente por sexos. Para los machos, la ecuación de von Bertalanffy estimó una $\mathrm{L}_{\infty}$ de $141.35 \mathrm{~mm}$ de $\mathrm{CL}$, una $\mathrm{K}$ de $1.21 \mathrm{y}^{-1}$, una $\mathrm{C}$ de 1.0 y un WP de 0.15 ; y para hembras la $\mathrm{L}_{\infty}$ fue de $117.55 \mathrm{~mm}$, la $\mathrm{K}$ de $1.60 \mathrm{y}^{-1}$, la C de $0.81 \mathrm{y}$ WP de 0.51 . Se estimó La tasa de mortalidad instantánea total (Z) en $9.53 \mathrm{y}^{-1}$ para los machos y $9.14 \mathrm{y}^{-1}$ para las hembras. La tasa instantánea de mortalidad natural (M) para los machos se estimó en $2.44 \mathrm{y}^{-1} \mathrm{y}$ en $3.09 \mathrm{y}^{-1}$ para las hembras. La tasa instantánea de mortalidad por pesca (F) se estimó en $7.09 \mathrm{y}^{-1}$ para los machos y $6.05 \mathrm{y}^{-1}$ para las hembras. La tasa de explotación se estimó en 0.74 para los machos y 0.66 para las hembras, lo cual sugiere que dicha población presenta sobrexplotación en ambos sexos. Se discute la necesidad de analizar las capturas y datos de esfuerzo de los 10 últimos años y aplicar otros métodos de evaluación del estoc para estimar la tendencia a largo plazo de esta pesquería.

Palabras clave: Macrobrachium macrobrachion, camarón, dinámica de poblaciones, Estuario del Cross River, Nigeria.

\section{INTRODUCTION}

The brackish river prawn, Macrobrachium macrobrachion, is an important component of the ecology of rivers and estuaries along the west coast of Africa, from Senegal (latitude $20^{\circ} \mathrm{N}$ ) to Angola (lat- itude $16^{\circ} \mathrm{S}$ ) (Holthuis, 1980). Its distribution, biology and artisanal fishery in the Lagos Lagoon were studied by Marioghae (Marioghae, 1982; 1990). He found that M. macrobrachion forms about $60 \%$ of all prawn landings in the lagoon, and together with Macrobrachium vollenhovenii, up to $83 \%$ of all 
Macrobrachium fishery catches during the rainy season.

In the Niger Delta, Powell (1983) found that $M$. macrobrachion is more important to the artisanal catch in the tidal areas than $M$. vollenhovenii. In the Cross River estuary, it constitutes $66 \%$ by weight and $81 \%$ by number in the landings of the artisanal Macrobrachium fishery (Enin, 1998), confirming its dominant position as the main target species of the fishery. The prawn is fished all the year round but with peak catches during the rainy months from May to October, which constitute the main fishing season (Enin 2000). Spawning and recruitment of the species also take place all year round but with seasonal pulses. The major spawning peak occurs between July and September, and a secondary peak in January; while recruitment peaks occur in May and December (Enin, 1997).

Comprehensive data on the demographic parameters are still lacking for many prawns that are key target species to the artisanal fisheries in Nigeria. This gap in information had been identified earlier by Powell (1983), who also reported that information on growth and mortality parameters of the prawn populations is invaluable to the effective management of the artisanal fisheries for which these prawns form the resource bases. A preliminary estimate of such population parameters for M. macrobrachion in the study area was attempted by Enin (1995). However, he did not take into account the possibility of sexual dimorphism in the population parameters, and such differences may affect the accuracy of the population parameter estimates that are used in stock assessment. Here, we aim to provide more detailed estimates of population and fishery parameters for both sexes, in order to determine the status of the fishery and to establish levels of exploitation that give sustainable yields. The method adopted is length-frequency analysis, which is suitable for invertebrate species whose individuals, unlike their vertebrate counterparts, cannot easily be aged and hence are not readily amenable to age-based analysis (Pauly et al., 1984).

\section{MATERIALS AND METHODS}

The length-frequency data used in the study were collected from the landings of the artisanal Macrobrachium fishery of the Cross River estuary, Nigeria, at Nsidung Beach, Calabar, which is a major prawn landing station on the left bank of the Calabar River $\left(4^{\circ} 58^{\prime} \mathrm{N}, 8^{\circ} 20^{\prime} \mathrm{E}\right)$. The prawn catches were sampled weekly for 18 months (January 1997 to June 1998) but were later pooled into monthly samples. During this period, a total of 15893 male specimens and 32475 female specimens of M. macrobrachion were measured. Total length $(\mathrm{mm})$ of the prawns was measured from the tip of the rostrum to the tip of the telson (FAO, 1981), to the nearest $0.5 \mathrm{~mm}$. Further analyses were conducted after all the data had been grouped into 5 $\mathrm{mm}$ class intervals. The prawns were caught using the beach seine and a hand-pushed trap net, both having $1 \mathrm{~cm}$ stretched mesh size throughout. The two gears are noted for their similarities in method of operation and catch composition. However, samples from the gears were weighted before being pooled to account for dissimilarity in catch contributions. During each sampling day at the beach, random sub-samples of prawns were collected from well-mixed catches of 2 canoes, and these added up to 8 canoes in each month.

The FiSAT (FAO-ICLARM Stock Assessment Tools) software was used to analyse the length-frequency data and to determine the growth and mortality parameters of the prawn. For growth analysis, the model incorporated into FiSAT is the seasonally oscillating version of the von Bertalanffy growth function (VBGF), which recognises the oscillations in growth rate due to fluctuations in environmental temperature during the annual cycle (Pauly and Gaschütz, 1979; Somers, 1988).

Using the ELEFAN I procedure available in FiSAT, the length-frequency data were first restructured by calculating a moving average over 5 length classes, and peaks were identified as those parts that are above the corresponding moving averages. Using the automatic search routine, the program then searches for the best combination of growth parameters $\left(\mathrm{L}_{\infty}, \mathrm{K}, \mathrm{C}, \mathrm{WP}\right)$ by plotting several growth curves through the length-frequency samples sequentially arranged in time, using the seed values as initial input data and applying variable starting points. A goodness-of-fit index $\left(\mathrm{R}_{\mathrm{n}}\right)$ was used to determine the quality of the growth curve; the best growth curve has the highest $R_{n}$ value (Gayanilo and Pauly,1997).

Initial inputs of 'seeded' growth parameter values required by ELEFAN I for the $\mathrm{L}_{\infty}$ value was obtained from Taylor's (1958) equation. For $M$. macrobrachion males $\mathrm{L}_{\max }$ was $124.00 \mathrm{~mm}$ and $\mathrm{L}_{(\infty)}$ 
was $130.53 \mathrm{~mm}$, while for females $\mathrm{L}_{\max }$ was 104.00 $\mathrm{mm}$ and $\mathrm{L}_{(\infty)}$ was $109.50 \mathrm{~mm}$. Asymptotic length $\left(\mathrm{L}_{\infty}\right)$ was also estimated using the Powell-Wetherall method. However, this method does not incorporate seasonal oscillations.

The instantaneous coefficient of total mortality (Z) was estimated using the seasonalised form of the length-converted catch curve (Pauly, 1990). The slope (b) of the curve with the sign changed provides an estimate of $Z$. The instantaneous rate of natural mortality (M) was estimated using Pauly's (1980) formula. The temperature used here was $26.7^{\circ} \mathrm{C}$ (Akpan and Offem, 1993).

The instantaneous rate of fishing mortality (F) was computed from the difference of instantaneous rates of total mortality and natural mortality, while the exploitation rate (E) was the ratio of instantaneous rate of fishing mortality to instantaneous rate of total mortality.

The probability of capture for a trawl-type selection was estimated for different size classes from the ratio of the expected numbers to those that were actually caught. By plotting these probabilities against the mid-length of the corresponding size classes, a resultant curve was obtained. From this curve, the length at first capture $\left(\mathrm{L}_{\mathrm{c}}\right)$ was estimated as the length corresponding to $50 \%$ probability of capture.

The seasonal recruitment pattern of M. macrobrachion was reconstructed by projecting the entire length-frequency data backward onto the time axis, and the data were fitted onto an arbitrary one-year time scale. This annual recruitment pattern was then fitted with Gaussian distributions using the maximum likelihood approach through the NORMSEP (normal separation) program incorporated into FiSAT.

The modified form of the Beverton and Holt (1964) relative yield-per-recruit (Y'/R) model, was used to estimate relative yield-per-recruit and relative biomass-per-recruit $\left(\mathrm{B}^{\prime} / \mathrm{R}\right)$, assuming both the knife-edge selection pattern and a selection ogive (Sparre and Venema, 1992; Gayanilo and Pauly, 1997), thus estimating the levels of exploitation that would result in optimum prawn yields. The analyses provided estimates of $\mathrm{E}_{\max }$ (the exploitation rate at which maximum relative yield-per-recruit is obtained), $\mathrm{E}_{0.1}$ (the exploitation rate at which the marginal increase in relative yield-per-recruit is $10 \%$ of its value at $\mathrm{E}=0$, and $\mathrm{E}_{0.5}$ (the exploitation rate corresponding to $50 \%$ of the unexploited relative biomass per recruit $\left(\mathrm{B}^{\prime} / \mathrm{R}\right)$.

The potential life span $\left(t_{\max }\right)$ of the prawns was estimated from the formula (Pauly, 1980).

\section{RESULTS}

The monthly length-frequency data used to estimate growth and mortality parameters of M. macro-

TABLE 1. - Monthly length-frequency data (total length, mm) for Macrobrachium macrobrachion males of the Cross River estuary, Nigeria, grouped in $5 \mathrm{~mm}$ class intervals (January 1997 to June 1998).

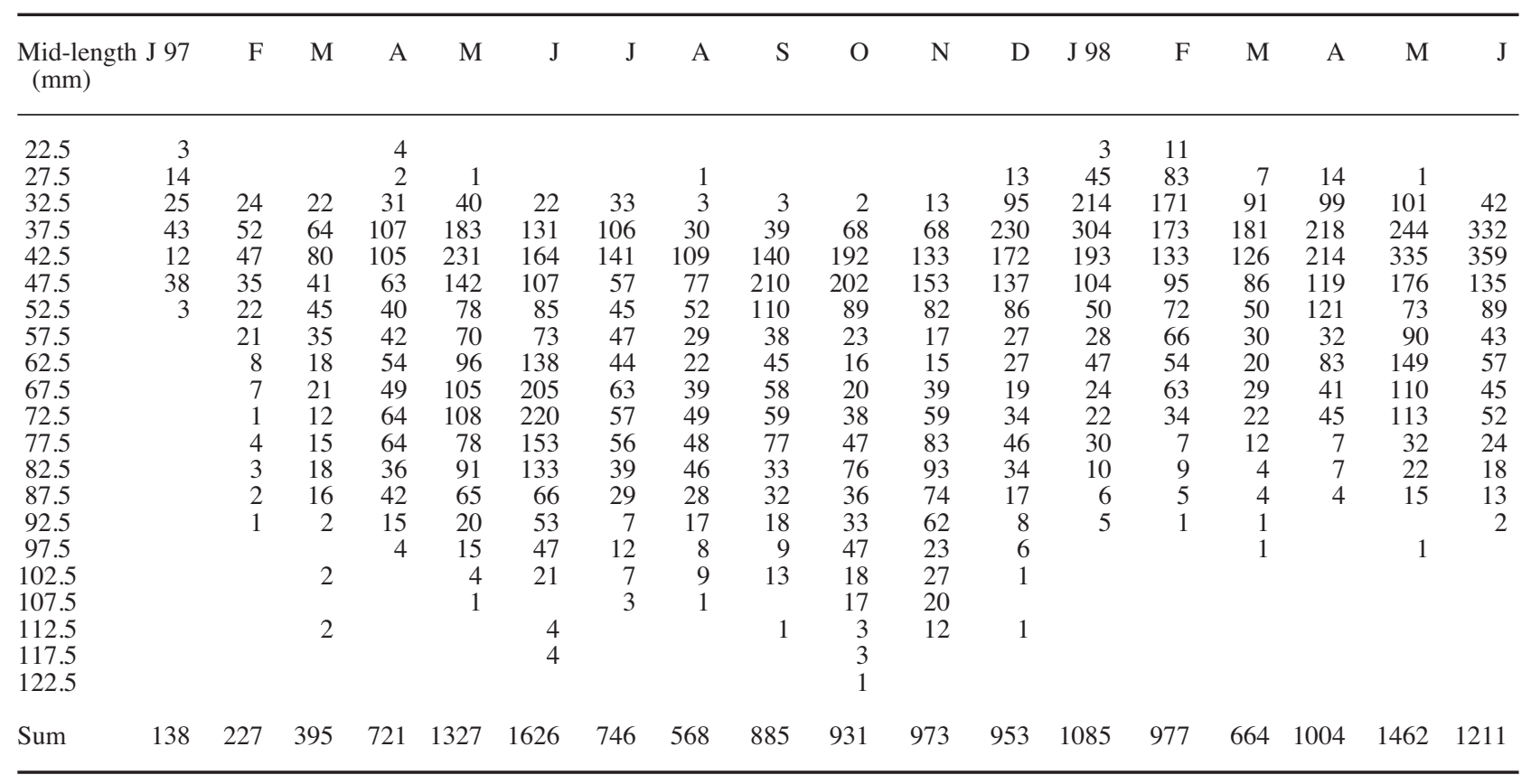


118 • F.M. NWOSU et al.

TABLE 2. - Monthly length-frequency data (total length, mm) for Macrobrachium macrobrachion females of the Cross River estuary, Nigeria, grouped in $5 \mathrm{~mm}$ class intervals (January 1997 to June 1998).

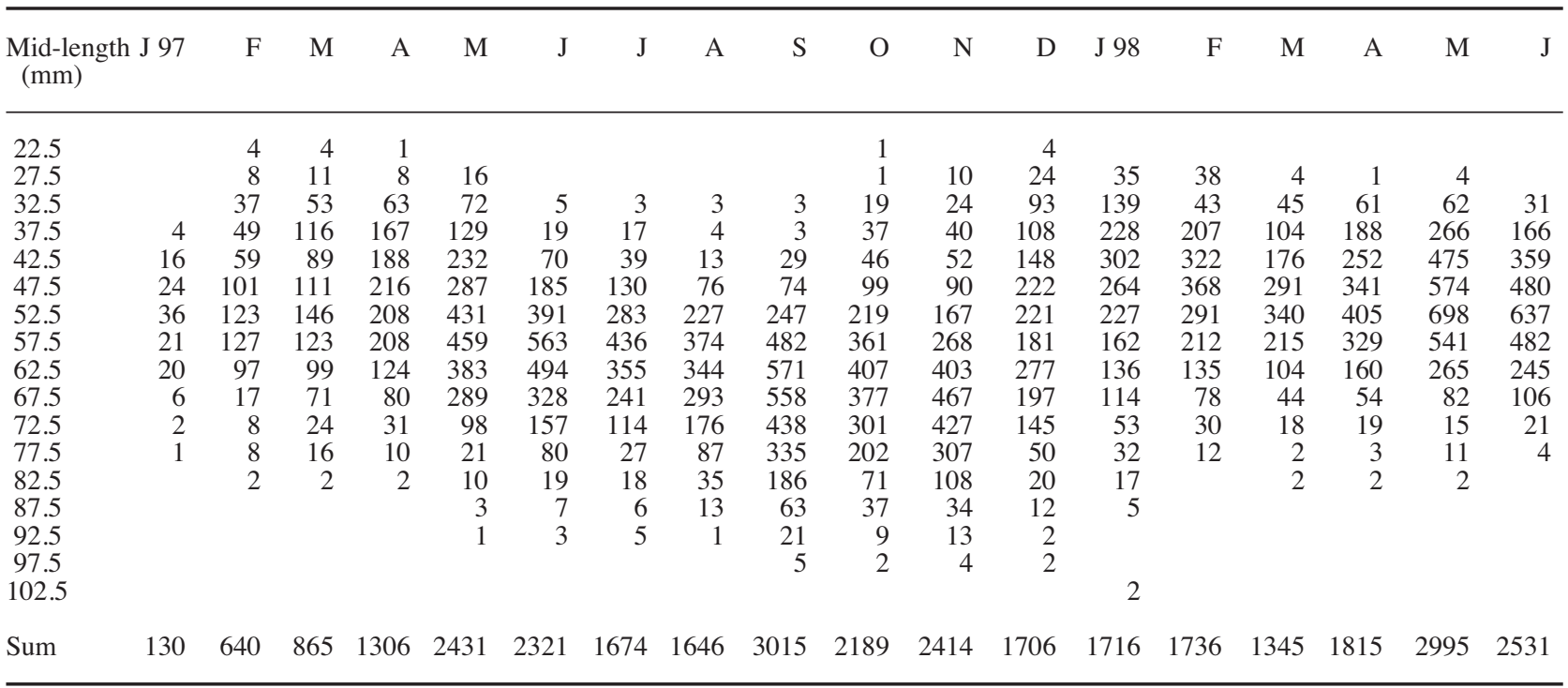

TABLE 3. - Summary of the growth parameter estimates for Macrobrachium macrobrachion males and females from the Cross River estuary, Nigeria. $\mathrm{L}_{\infty}=$ asymptotic length, $\mathrm{L}_{\max }=$ maximum length observed in samples, $\mathrm{K}=$ growth coefficient, $\mathrm{C}=$ amplitude of seasonal growth oscillation, $\mathrm{WP}=$ winter point, $\mathrm{R}_{\mathrm{n}}=$ goodnessof-fit index.

\begin{tabular}{lcccccc}
\hline & $\begin{array}{c}\mathrm{L}_{\infty} \\
(\mathrm{mm})\end{array}$ & $\begin{array}{c}\mathrm{L}_{\max } \\
(\mathrm{mm})\end{array}$ & $\begin{array}{c}\mathrm{K} \\
\left(\text { year-1 }^{-1}\right)\end{array}$ & $\mathrm{C}$ & $\mathrm{WP}$ & $\mathrm{R}_{\mathrm{n}}$ \\
\hline males & 141.35 & 124 & 1.21 & 1.00 & 0.15 (Feb.) & 0.205 \\
females & 117.55 & 104 & 1.60 & 0.81 & 0.51 (July) & 0.377 \\
\hline
\end{tabular}

brachion are provided in Tables 1 (males) and 2 (females). The estimated growth parameters for both sexes are given in Table 3. For the males, the growth parameters were: $\mathrm{L}_{\infty}=141.35 \mathrm{~mm}, \mathrm{~K}=1.21$ year $^{-1}$,

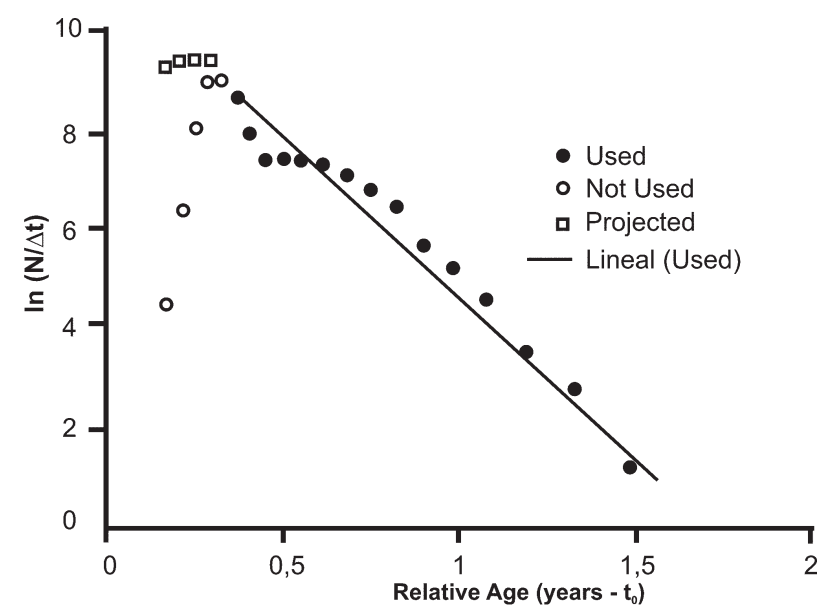

FIG. 1. - Length-converted catch curve of M. macrobrachion males of the Cross River estuary, Nigeria, 1997 to 1998 (calculated Z = 9.53 year $\left.^{-1}\right)$.

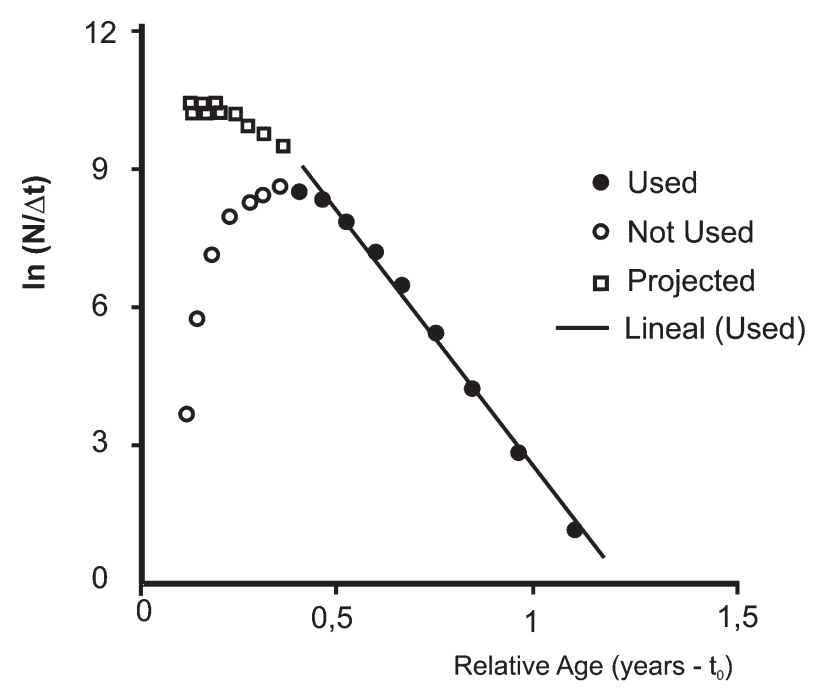

FIG. 2. - Length-converted catch curve of M. macrobrachion females of the Cross River estuary, Nigeria, 1997 to 1998 (calculated $\mathrm{Z}=9.14$ year $^{-1}$ ).

$\mathrm{C}=1.0$, and $\mathrm{WP}=0.15$. For the females, they were: $\mathrm{L}_{\infty}=117.55 \mathrm{~mm}, \mathrm{~K}=1.60$ year $^{-1}, \mathrm{C}=0.81$, and $\mathrm{WP}$ $=0.51$. Estimates of $\mathrm{L}_{\infty}$ using the Powell-Wetherall method were $130.42 \mathrm{~mm}$ for the males $(\mathrm{r}=-0.991)$, and $107.31 \mathrm{~mm}$ for the females $(\mathrm{r}=-0.991)$. The approximate longevity $\left(\mathrm{t}_{\max }\right)$ of $M$. macrobrachion of the Cross River estuary was estimated at 29.8 months or about 2.5 years for the males, and 22.5 months or about 2 years for the females, which represent the maximum life spans of the prawns in their natural environment.

The instantaneous rate of total mortality $(\mathrm{Z})$ as estimated from the length-converted catch curve 

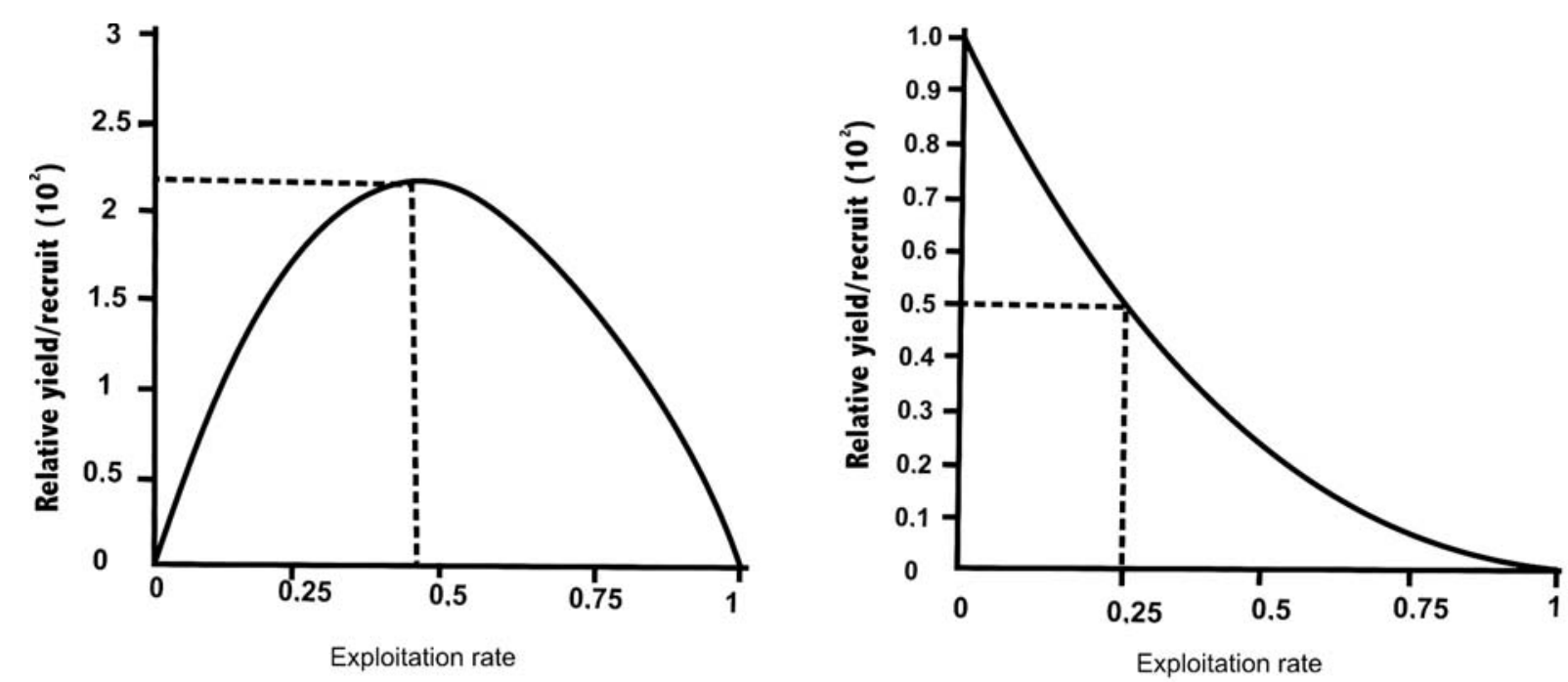

FIG. 3. - Relative yield-per-recruit (left) and relative biomass-per-recruit (right) for M. macrobrachion males of the Cross River estuary, Nigeria, based on the selection ogive option $\left(\mathrm{E}_{\max }=0.46, \mathrm{E}_{0.1}=0.42, \mathrm{E}_{0.5}=0.28\right)$.

procedure, was 9.53 year $^{-1}$ for the males (Fig. 1) and 9.14 year $^{-1}$ for the females (Fig. 2). The instantaneous rate of natural mortality $(\mathrm{M})$ as estimated from Pauly's (1980) empirical formula was 2.44 year-1 for the males and 3.09 year-1 $^{-1}$ for the females, so the instantaneous rate of fishing mortality $(\mathrm{F})$, considering $\mathrm{F}=\mathrm{Z}-\mathrm{M}$, is 7.09 year $^{-1}$ for the males and 6.05 year $^{-1}$ for the females. These resulted in the exploitation rates $(\mathrm{E}=\mathrm{F} / \mathrm{Z})$ of 0.74 for the males and 0.66 for the females.

The relative yield-per-recruit $\left(\mathrm{Y}^{\prime} / \mathrm{R}\right)$ analysis based on the assumption of knife-edge selection gave the following results: $\mathrm{E}_{\max }=0.59, \mathrm{E}_{0.1}=0.56$, and $\mathrm{E}_{0.5}=0.32$ for the males; and $\mathrm{E}_{\max }=0.68, \mathrm{E}_{0.1}=$ $0.62, \mathrm{E}_{0.5}=0.30$ for the females. The $\mathrm{Y}^{\prime} / \mathrm{R}$ estimates

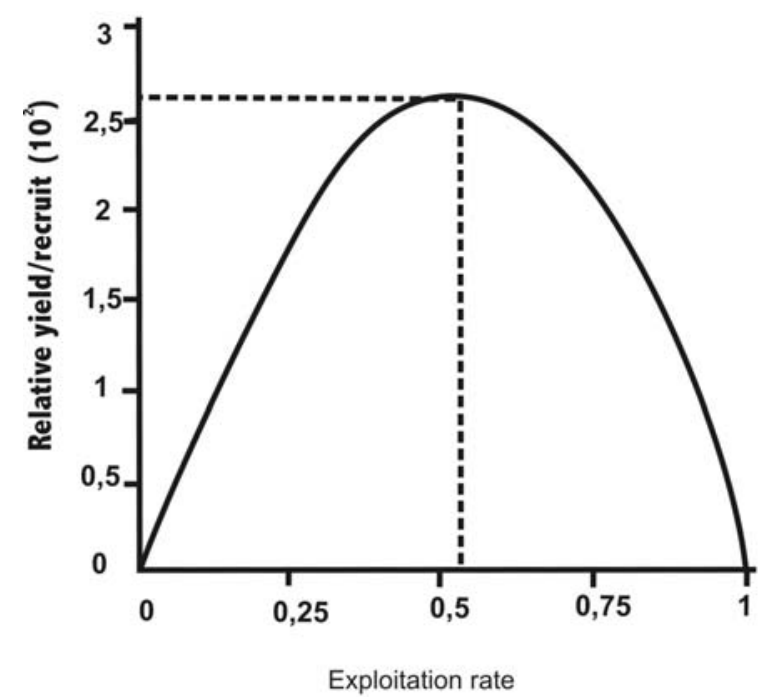

applying the selection ogive option gave the following results: $\mathrm{E}_{\max }=0.46, \mathrm{E}_{0.1}=0.42$, and $\mathrm{E}_{0.5}=0.28$ for the males (Fig. 3); and $\mathrm{E}_{\max }=0.53, \mathrm{E}_{0.1}=0.51$, and $\mathrm{E}_{0.5}=0.31$ for the females (Fig. 4).

\section{DISCUSSION}

The growth curve estimated in this study for $M$. macrobrachion indicates a seasonal growth, and that in a certain period of the year growth drastically slows down as in the females $(\mathrm{C}=0.81)$, or may completely cease as in the males $(\mathrm{C}=1.0)$. For the males, the estimated winter point (WP) of 0.15 means that growth is poorest in February, while the

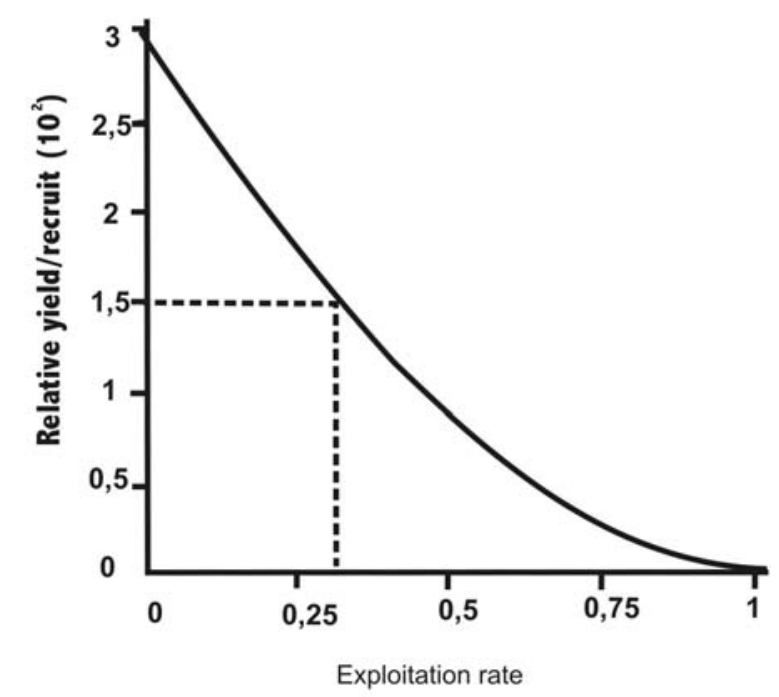

FIG. 4. - Relative yield-per-recruit (left) and relative biomass-per-recruit (right) for M. macrobrachion females of the Cross River estuary, Nigeria, based on the selection ogive option $\left(\mathrm{E}_{\max }=0.53, \mathrm{E}_{0.1}=0.51, \mathrm{E}_{0.5}=0.31\right)$. 
WP of 0.51 for the females implies that the poorest growth occurs in July. The poorest growth of the males in February may be associated with the migration of the prawns out of the Cross River estuary into the freshwater portions of the river during the dry months of February and March, as the salinity in the estuary increases beyond their range of tolerance (Marioghae, 1982). A poor condition of aquatic organisms is usually observed during the period of migration, which may be reflected in a drastically reduced growth rate.

Furthermore, the months of February and March are about the warmest in the year, with surface water temperatures generally above $30^{\circ} \mathrm{C}$. Helffman et al . (1997) note that in temperate waters feeding often slows down or ceases in the summer, when temperatures reach $29^{\circ} \mathrm{C}$ or higher.

The poorest growth of the females in July may be associated with their reproductive activities in the period. M. macrobrachion in the estuary spawns all the year round but this comes to a peak in July to September (Enin, 1997). It is conceivable that during the peak spawning period, much of the ingested food materials may be sequestrated into the development of the gonads, thus resulting in poor somatic growth (Helffman et al., 1997). The poorest growth of the prawns in this estuary in July had earlier been noted by Enin (1995).

The estimated values of the growth coefficient $(\mathrm{K})$ of 1.21 year $^{-1}$ for the males and 1.60 year $^{-1}$ for the females fall within the range of values $(0.39$ year ${ }^{-1}$ to 1.60 year $^{-1}$ ) estimated for many penaeid shrimp stocks by Pauly et al. (1984). The $\mathrm{L}_{\infty}$ estimates of $141.12 \mathrm{~mm}$ (males) and $117.55 \mathrm{~mm}$ (females) compare with the maximum length of $130 \mathrm{~mm}$ observed for the species in the Lagos Lagoon (Marioghae, 1982). The estimated values of $\mathrm{L}_{\infty}$ for M. macrobrachion males using PowellWetherall, however, agrees with Marioghae's (1982) $130 \mathrm{~mm}$ for the species in Lagos Lagoon. The Powell-Wetherall method was not used for further calculations in this study because it does not consider seasonal oscillation, which is prevalent in the tropics (Gayanilo and Pauly, 1997). The growth of most fish species apparently conforms to the von Bertalanffy growth model. For crustaceans, the individual growth does not conform to this model, but to some stepwise curve, with each step accounting for a moult (Sparre and Venema 1992). However, since members of a cohort of crustaceans do not moult at the same time, the average growth curve of a cohort smoothens out, approximating the von Bertalanffy growth function (Pauly et al., 1984). The sex-specific differences in size and growth of the prawns observed here are common features for most fish and prawn species (Pauly et al., 1984).

The presence of two recruitment peaks per year found here for the populations of male and female M. macrobrachion is in accordance with earlier results on prawns in tropical regions (Pauly et al., 1984), and confirms the assertions of Pauly (1982), and Dwiponggo et al. (1986) that the two recruitment pulses per year may be typical of tropical fish and invertebrate stocks. As for most tropical fisheries, recruitment in this fishery is continuous, though two peaks are identified over an arbitrary year. The difference in peaks of recruitment between males and females is traceable to sex-specific variations in growth rates, leading to different asymptotic lengths. Using the length-frequency data, position of recruitment peak may be inferred approximately by examining the periods with high frequency of young, small-sized prawns in the sample, observed generally in May-June and December-January for both the male and female, which is similar to results obtained earlier by Enin (1995).

The instantaneous rate of total mortality $(\mathrm{Z})$, estimated here as 9.53 year $^{-1}$ (males) and 9.14 year $^{-1}$ (females), is slightly lower than but comparable to an earlier estimate (10.6 year-1, Enin, 1995). The higher natural mortality rate (M) for the female prawns may indicate that a higher proportion of female prawns die of natural causes than the males. Ecological evidence for this is hard to find, but given that the females attain a smaller maximum size than the males, they may be exposed to a larger suite of predators than the males, resulting in a higher $\mathrm{M}$ in the females. Furthermore, the fact that the females carry eggs on their belly during the spawning process may make them less agile than the males, resulting in easier capture by predators. It is also noteworthy that the females have a lower longevity $\left(\mathrm{t}_{\max }=22.5\right.$ months $)$ in the natural environment than the males $\left(t_{\max }=29.8\right.$ months).

The exploitation rate $(\mathrm{E}=\mathrm{F} / \mathrm{Z})$ is the fraction of the total mortality of the prawns caused by the artisanal fishery. The estimates of $\mathrm{E}$ of 0.74 for the males and 0.66 for the females indicates that these prawn populations were under excessive fishing pressure. This is based on the assumption of Gulland (1971) that in an optimally exploited stock the natu- 
ral and the fishing mortalities should be equal, i.e. $\mathrm{E}$ $=F / Z=0.5$. Comparing this result with the relative yield-per-recruit analysis would seem to confirm this assertion that the prawn populations are overfished. For the males, $\mathrm{E}_{\max }$ (the exploitation rate that would give maximum relative yield-per-recruit) estimated as 0.46 is much lower than the actual exploitation rate of 0.74 . For the females, the estimated actual exploitation rate of 0.66 was much higher than $\mathrm{E}_{\max }=0.53$. Also, in both the males and the females, the actual exploitation rate (E) estimates were higher than $\mathrm{E}_{0.5}$ (the exploitation rate at which the relative biomass per recruit $\left(\mathrm{B}^{\prime} / \mathrm{R}\right)$ of the virgin stock is halved. All this indicates that the $M$. macrobrachion population of the Cross River estuary is largely over-fished, a conclusion earlier reached by Enin (1995).

The results here suggest the need for urgent management measures to be instituted for this fishery in order to prevent further deterioration in the stock situation of this prawn resource, and also the attendant socioeconomic consequences to the immediate fishing communities. Macrobrachium prawns live in freshwaters but the larval stages require brackish water conditions for survival and optimum development (New and Singholka, 1985). Hence, the spawning adults migrate to the estuaries, where they may be exposed to much fishing pressure. In the Cross River estuary, this exploitation of the spawning biomass has been considered non-conservative to the stock and responsible for the deterioration of the prawn population (Enin, 1997). There is a need to analyse the catch and effort data at least for the last 10 years and to apply other methods of stock assessment in order to estimate the long term trends in the fishery.

\section{ACKNOWLEDGEMENTS}

We are grateful to the Forschungszentrum Jülich Internationales Büro, Germany, for funding a fourmonth research stay of the first author at the Centre for Tropical Marine Ecology (ZMT), University of Bremen, Germany, where much of the analysis was conducted.

\section{REFERENCES}

Akpan, E.R. and J.O. Offem. - 1993. Seasonal variation in water quality of the Cross River, Nigeria. Rev. Hydrobiol. Trop., 26 (2): $95-103$.

Beverton, R.J.H. and S.J. Holt. - 1964. Tables of yield functions for fishery assessment. FAO Fish. Tech. Pap., (38), 49 pp.

Dwiponggo, A., T. Hariati, S. Banon, M. L. Palomares, and D. Pauly. - 1986. Growth, mortality and recruitment of commercially important fishes and penaeid shrimps in Indonesian waters. ICLARM Tech. Rep., (17), ICLARM, Manila, 91 pp.

Enin, U.I. - 1995. First estimates of growth, mortality and recruitment parameters of Macrobrachium macrobrachion Herklots, 1851 in the Cross River estuary, Nigeria. Dana, 11(1): 29-38.

Enin, U.I. - 1997. Formulation of management strategies for two exploited West African prawn populations. Fish. Manage. Ecol., 4: 301-309.

FAO. - 1981. Methods of collecting and analysing size and age data for fish stock assessment. FAO Fish. Circ., (736), 100 pp.

Gayanilo, F. C., Jr. and D. Pauly (eds.).-1997. The FAO-ICLARM Stock Assessment Tools (FiSAT): Reference Manual. FAO Computerized Information Series - Fisheries, (8). ICLARM, Manila and FAO, Rome, $262 \mathrm{pp}$.

Gulland, J. A. (Editor). - 1971. The fish resources of the ocean. Fishing News (Books) Ltd., Farnham, Surrey.

Helffman, G.S., B.B. Collette and D.E. Facey. - 1997. The diversity of fishes. Blackwell Science, Abindon.

Hoenig, J.M., J. Csirke, M.J. Sanders, A. Abella, M.G. Andreoli, D. Levi, S. Ragonese, M. Al-Shoushani, and M.M. El-Musa. 1987. Data acquisition for length-based stock assessment: report of Working Group I. In: D. Pauly and G.R. Morgan (eds.), Length-based methods in fisheries research. ICLARM Conference Proceedings, (13), ICLARM, Manila, pp. 343-352.

Holthuis, L.B. - 1980. FAO Species catalogues. Vol. 1. Shrimps and prawns of the world. An annotated catalogue of species of interest to fisheries. FAO Fish. Synop., (125), Vol. 1. 271 pp.

Marioghae, I.E. - 1982. Notes on the biology and distribution of Macrobrachium vollenhovenii and Macrobrachium macrobrachion in the Lagos lagoon (Crustacea, Decapoda, Palaemonidae). Rev. Zool. Afr., 96(3): 493-508.

New, M. B. and S. Singholka. - 1985. Freshwater prawn farming: a manual for the culture of Macrobrachium rosenbergii. FAO Fish. Tech. Pap., (225, Rev. 1), 118 pp.

Pauly, D. - 1980. On the interrelationships between natural mortality, growth parameters, and mean environmental temperature in 175 fish stocks. J. Conseil, CIEM, 39 (2): 175-190.

Pauly, D. - 1984. Fish population dynamics in tropical waters: a manual for use with programmable calculators. ICLARM Studies and Reviews, (8), $325 \mathrm{pp}$.

Pauly, D. - 1990. Length-converted catch curve and seasonal growth of fishes. Fishbyte, 8 (3): 33-38.

Pauly, D. and G. Gaschütz. - 1979. A simple method for fitting oscillating length growth data, with a program for Pocket Calculators. ICESCM 1979/G: 24, Demersal Fish Committee, 26 pp.

Pauly, D., J. Ingles, and R. Neal. - 1984. Application to shrimp stocks of objective methods for the estimation of growth, mortality and recruitment-related parameters from length-frequency data (ELEFAN 1 and 2). In: J.A. Gulland and B.J. Rothschild (eds.), Penaeid shrimps - their biology and management, pp. 220-234. Fishing News (Books Ltd., Farnham, Surrey.

Powell, C.B. - 1983. Fresh- and brackish-water shrimps of economic importance in the Niger Delta. In: Proceedings of $2^{\text {nd }}$ Annual Conference of Fisheries Society of Nigeria (FISON), Calabar, 25-27 January, 1982, pp. 254-285.

Sommers, I. F. - 1988. On seasonally oscillating growth function. Fishbyte, 6(2): 8-11.

Sparre, P. and S.C. Venema. - 1992. Introduction to tropical fish stock assessment, part 1 - manual. FAO Fish. Tech. Pap., (306.1), Rev. 1. 376 pp.

Received April 4, 2005. Accepted October 13, 2006.

Scient. ed.: F. Sardà.

Published online February 26, 2007. 
